\title{
The Development of Tcd Software And its Impact on Academic Writing: A Case on Malaysian Graduated Students
}

Ramlan Mustapha, Nor Hapizah M.Borhan, M.Nasrul Hakim Roslan, Wan Azmi Wan Ahmad, Asjad Mohamad

To Link this Article: http://dx.doi.org/10.6007/IJARBSS/v11-i7/10439

DOI:10.6007/IJARBSS/v11-i7/10439

Received: 10 May 2021, Revised: 12 June 2021, Accepted: 24 June 2021

Published Online: 04 July 2021

In-Text Citation: (Mustapha et al., 2021)

To Cite this Article: Mustapha, R., M.Borhan, N. H., Roslan, M. N. H., Ahmad, W. A. W., \& Mohamad, A. (2021). The Development of Tcd Software And its Impact on Academic Writing: A Case on Malaysian Graduated Students. International Journal of Academic Research in Business and Social Sciences, 11(7), 282-291.

Copyright: @ 2021 The Author(s)

Published by Human Resource Management Academic Research Society (www.hrmars.com) This article is published under the Creative Commons Attribution (CC BY 4.0) license. Anyone may reproduce, distribute, translate and create derivative works of this article (for both commercial and non-commercial purposes), subject to full attribution to the original publication and authors. The full terms of this license may be seen at: http://creativecommons.org/licences/by/4.0/legalcode

Vol. 11, No. 7, 2021, Pg. 282 - 291

Full Terms \& Conditions of access and use can be found at http://hrmars.com/index.php/pages/detail/publication-ethics 


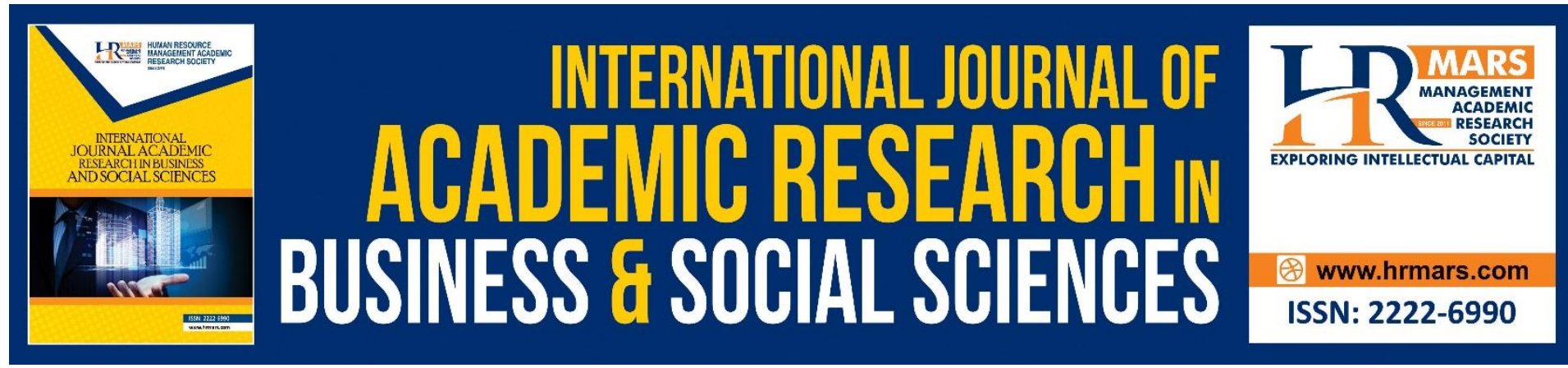

\title{
The Development of Tcd Software And its Impact on Academic Writing: A Case on Malaysian Graduated Students
}

\author{
${ }^{1}$ Ramlan Mustapha, ${ }^{2}$ Nor Hapizah M.Borhan, ${ }^{3}$ M.Nasrul Hakim \\ Roslan, ${ }^{4}$ Wan Azmi Wan Ahmad, ${ }^{5}$ Asjad Mohamad \\ 1,3Universiti Teknologi MARA Pahang, Raub Campus, Malaysia, 2, 4,5Universiti Teknologi \\ MARA Pahang, Jengka Campus, Malaysia, Academy of Contemporary Islamic studies, \\ Universiti Teknologi MARA Pahang, Malaysia
}

\begin{abstract}
Academic writing is essential for students to complete their studies successfully and to compete professionally. University students are required to write based on various styles and are evaluated for their ability to write proficiently. This Table Connector Design (TCD) software is developed to improve writing skills, organise facts and organize academic writing data more systematically. It was developed to offer a fast, easy and user-friendly approach to academic writing that organises facts as found in the literature. The software also helps arrange ideas and facts in the form of a table that can be arranged and rearranged quickly and accurately to suit changing contexts and purposes. This study uses the Design and development research method initiated by Richey \& Klein. This study was conducted by distributing questionnaires online using Google form to 37 software users and make interviews with 7 software users. The quantitative data obtained were then analysed using excel format, while interview data were analyzed using qualitative data analysis method. The findings of the study showed that, most users were satisfied with the software, $75 \%$ stated that it is easy to use, $95 \%$ easy to understand, $85 \%$ easy to use and $78 \%$ stated that the software meets their writing needs. While the qualitative findings show that all users stated that this software helps them a lot to write better and structured.
\end{abstract}

Keywords: TCD, Writing Skill, Academic Writing, Software.

\section{Introduction}

Since writing is a crucial factor in academic and career success, students need to be able to write independently of every support and technological method. Writing abilities, such as skills, strategies for writing, writing in a way that communicates ideas clearly and concisely, builds reasoned arguments, organises evidence and generated ideas. These skills are critical and are applied widely. A student's inability to express ideas in writing with accuracy and sophistication risks them being rejected from colleges, universities and many areas of professional employment. 
Students need to acquire writing skills to graduate from university and college and compete in a highly competitive global economy. It is, therefore, essential to introduce students to formal writing and provide an opportunity to produce formal academic reports. Industry requires people to write with grammatical precision, examine a subject thoroughly, and present evidence-based arguments logically and coherently (Alhusban, 2016).

\section{Problem Statement}

The rapid advancement of technology has had a significant impact on learning and writing in numerous ways. It has drastically changed the way people learn, communicate and write in many way. It has successfully altered our civilization by expanding the communication system, technology, learning in helping people in enhance their knowledge. Computers have enabled access to large amounts of data and can surely aid in the learning process (Ghahri, Hashamdar, \& Mohamadi, 2015). Based on the availability of this technology, it should be an academic writing process, learning is not a problem because with the help of easy access technology, writing can be done well. But now, there are many students who are not able to write well, especially in foreign languages and so on. For example, (Abdel Karim, 2013) conducted a research at UITM Malaysia on students from Arab countries, faced problems in academic writing. English language proficiency and writing methods have an impact on them and writing performance in academic specifically.

In Other circumstances, there are numerous contexts in higher education research that consider difficulty in the writing process, including literacy perspectives, knowledge, technical aspects of writing, language features, and linguistic and cultural background differences (Lea, 2014). According to Cumming, Lai, and Cho (2016), developing the ability to integrate source material efficiently and appropriately into written compositions is a major barrier for students learning to write for academic purposes. They discovered that students struggled with the complicated processes of writing from sources, but developed techniques to deal with them; past knowledge and experience influenced students' success in writing from sources (Supriyadi et al., 2020). Based on the above findings, it can be concluded that, writing skills not all students can master it well. There are constraints and needs that are necessary to help overcome the weaknesses in academic writing especially from the aspect of technological assistance in facilitating the writing process. Therefore, the researcher sees this writing problem, can be overcome with the help of available technology to give students an understanding of how to process writing correctly and well based on the help of writing technology.

\section{What is TCD?}

TCD (Table Connector Design) is a software developed to help organise and expedite academic writing. It addresses the problem faced by new students in various fields of study, organizing and gathering information and writing facts. TCD is developed in the form of electronic software in accordance with Microsoft Windows. It is easy to use, as it is built with a user-friendly concept and is easy to operate. This simple and precise concept is needed to accelerate the comprehension process and improve writing skills so that the layout and facts in academic writing can be coordinated. It is a writing tool that helps organise ideas and presents them clearly and systematically. 


\section{Literature}

Several researchers participated in the development of computer programmes that contribute to writing skills assessment and feedback. In Burstein, Khodorov and Leacock (Parra \& Calero, 2019), writing can be improved most effectively by writing frequently and receiving immediate and proper feedback. Furthermore, Automated Writing tools as an assistant tool that provides high-level feedback and writing quality are growing (Wilson \& Czik, 2016). Academic writing is completely different from high school writing. It equates to the development of effective writing skills in the context of academic communication. Academic writing aims to develop and strengthen the skills of students/graduated students from various specializations and faculties in writing such as reports, articles, diploma papers, dissertations, presentations, essays, and so on (Todorova \& Koleva, 2019).

\section{Technology and Writing}

Writing is the first step towards better pedagogy and learning outcomes in the composition classroom. Research has shown that digital tools have a positive impact on the writing process. They increase feedback and communication with authentic audiences and multimodal composition opportunities (Noble \& Paganucci, 2015). The quality of student writing skill also improved with word processing and other tools compared to pencil and paper, and the quality incrementally improved as grade level increased (Noble et al., 2015).

A collaborative study by the Pew Research Centre and National Writing Project has also shown the benefits of digital devices in the composition classroom as increasing collaboration among student writers and authentic audiences. The study examined 2462 professors, asking them how their schools and students are affected by digital tools (Purcell, Buchanan, \& Friedrich, 2013).

Due to increased access to and use of such programmes, research on student writing in multimodel web-based technologies, such as Wiki platforms such as Google Sites and blogs, is still emerging. The transition from the alphabet to multimodal works through the use of current technology has been addressed by Pamela Takayoshi and Cynthia L. Selfe (2007). The integration of digital tools in a classroom can enhance the quality of writing by promoting students' knowledge. This has been demonstrated with word processing by Goldberg, Russell, and Cook (2003), while the Wiki suggest potential advantages by Dymock and by Hughes (2009) and Wheeler, Yeomans, and Wheeler (2008). In particular, tools that encourage cooperation and offer authentic viewers can improve peer review, teacher feedback and lead to critical thinking (Purcell, Buchanan, \& Friedrich, 2013). The literature suggests that certain applications can aid writing. Furthermore, the current world needs technology in helping to accomplish something, as well as in academic writing. Therefore, we developed this application to help accelerate writing by providing a guideline, methods, and skills to help in effective academic writing.

\section{Methodology}

The design and development research (DDR) approach is used to develop the software. Due to its pragmatism in testing theory and validating its practicality, the use of DDR as a select approach is justified. In addition, new methods, techniques and tools based on specific analysis of needs have been described (Richey \& Klein, 2007). This methodology is also known formerly as research into development (Richey, Klein \& Nelson, 2004), research based on 
design (Reeves, 2006; Herrington et al., 2007), and research on design (Bannan-Ritland, 2003; Van der Akker, 2007).

\section{Respondents}

This study involved several phases, however in the evaluation phase, the researcher made 2 methods to obtain software effectiveness data. First, the researcher distributed questions in the form of Google form to 37 software users and second, the researcher made unstructured interviews over the phone to the users. The findings will be discussed in the next section.

\section{Development Phase and data analysis}

The development of this software contains four main phases: the needs analysis phase, design phase, development phase, and evaluation phase. Each phase contains a specific method that is the needs analysis phase of the researcher to identify the problem, then the design phase of the researcher to formulate a basic software model, the third phase builds software while the fourth phase evaluates the usability of software feedback results from software users.

\section{First Phase: Need analysis phase finding}

After identifying the problems faced by most $\mathrm{PhD}$ and master students in writing their theses, they faced problems organizing the content and structuring the writing to be more systematic. Most freshmen have trouble organizing factual names and coordinating literature sources in writing. This causes students to often lose direction and lack focus in writing.

\section{Second Phase: Design (Flow board)}

The phase sees the researcher building a flow board in compiling this software. This includes arranging the main items according to the prioritized needs.
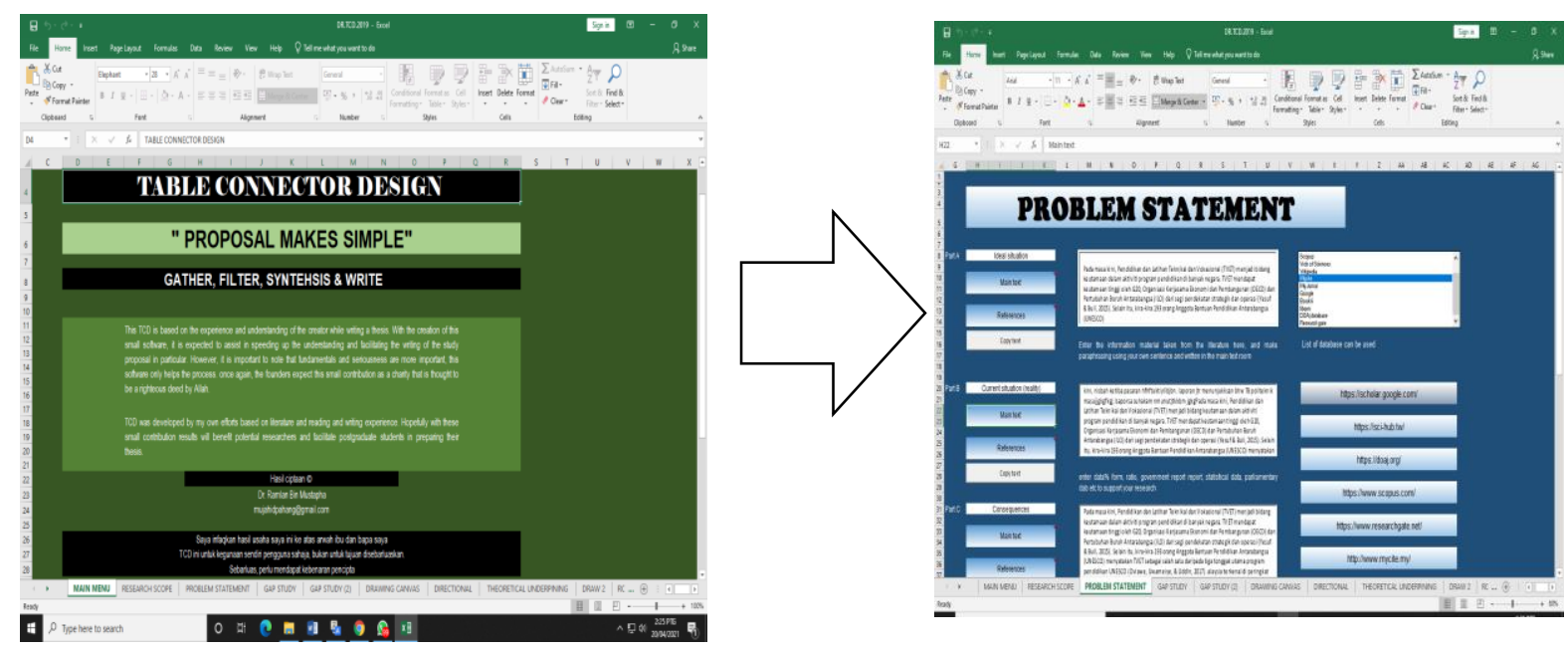

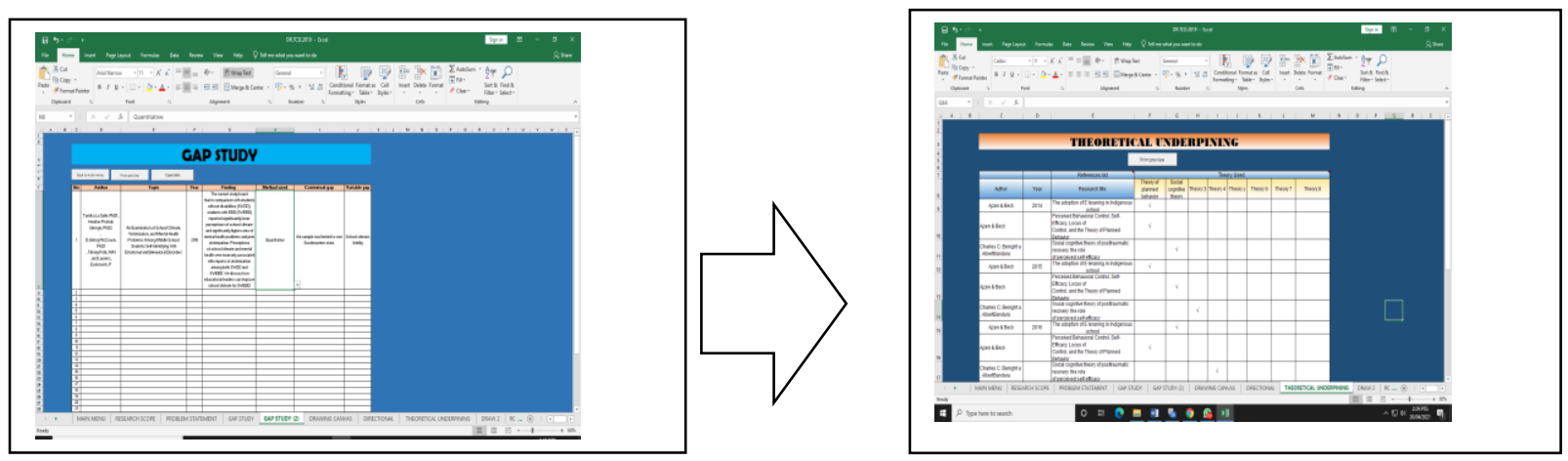

Figure 1: Design flow for design phase

\section{Third Phase: Software Development}

The third phase involves software development. Construction is based on flow mapping in advance, which contains the parts that need to be followed to use it correctly during the writing process.
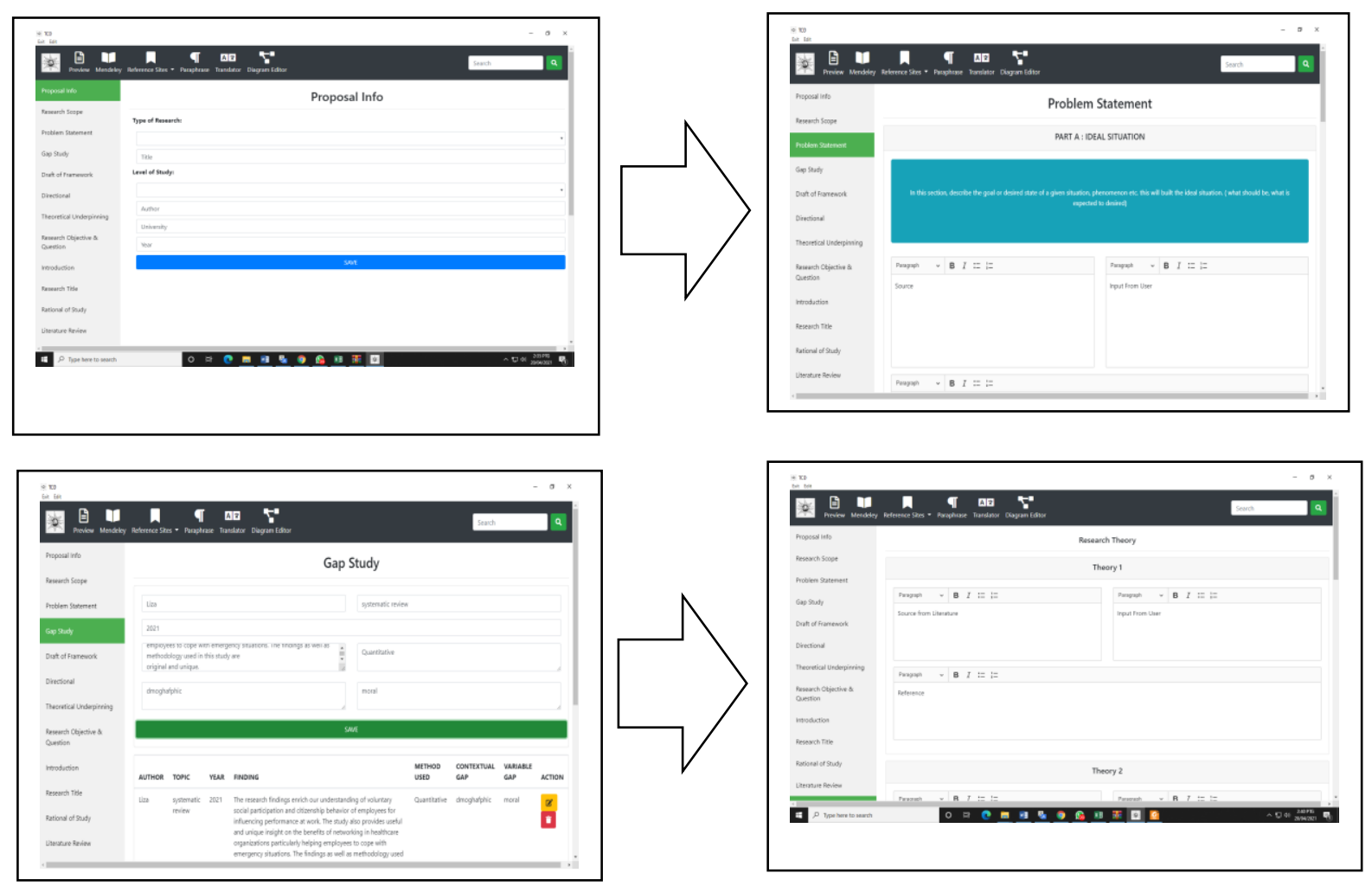

Figure 2: Software development phase

\section{Fourth Phase: Evaluation}

The fourth phase evaluates the product. Researchers receive feedback from users obtained from interviews distributed via Google Forms about the product.

\section{Findings}

In this section, the researcher will describe specifically the findings of the study that has been conducted. The findings will be presented in two parts, namely quantitative findings and qualitative findings by interview. These findings are to show the impact of software on 
students' academic writing, especially in thesis writing. The findings of the study are presented in the following diagrams and descriptions:

The Feedback from international user (Indonesia

Even though for paid journal articles,

doktor?

What button do we press to download the articles, doktor? And what about the updated version of TCD for Mac, is it already realesed? Many thanks before, doctor

May Allah Ta'ala give me an opportunity to invite you to Sulawesi, Indonesia to presenting TCD there, Amin $6: 18 \mathrm{pm}$ +60 16-2161223 Even though for paid journal articles, doktor? Yes.. and at the same time we can use the

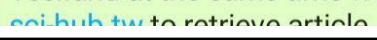

(From Local User)

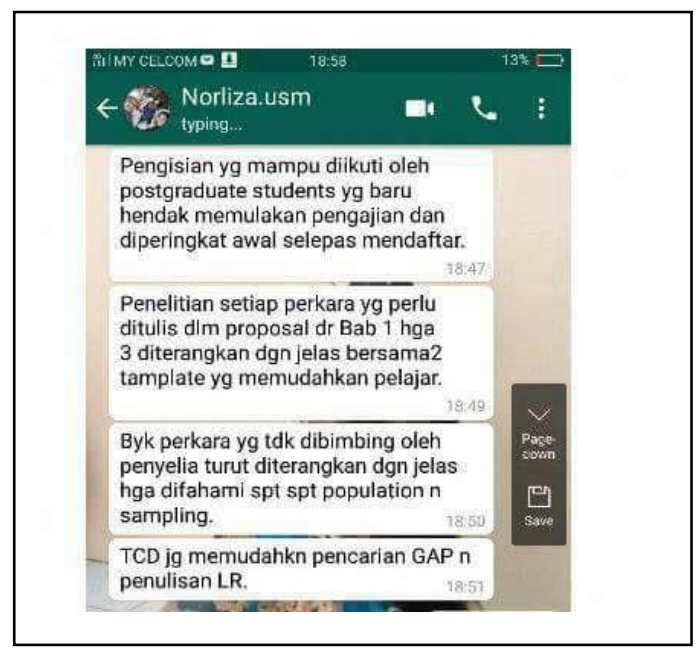

Figure 3: Feedback from international \& Local User

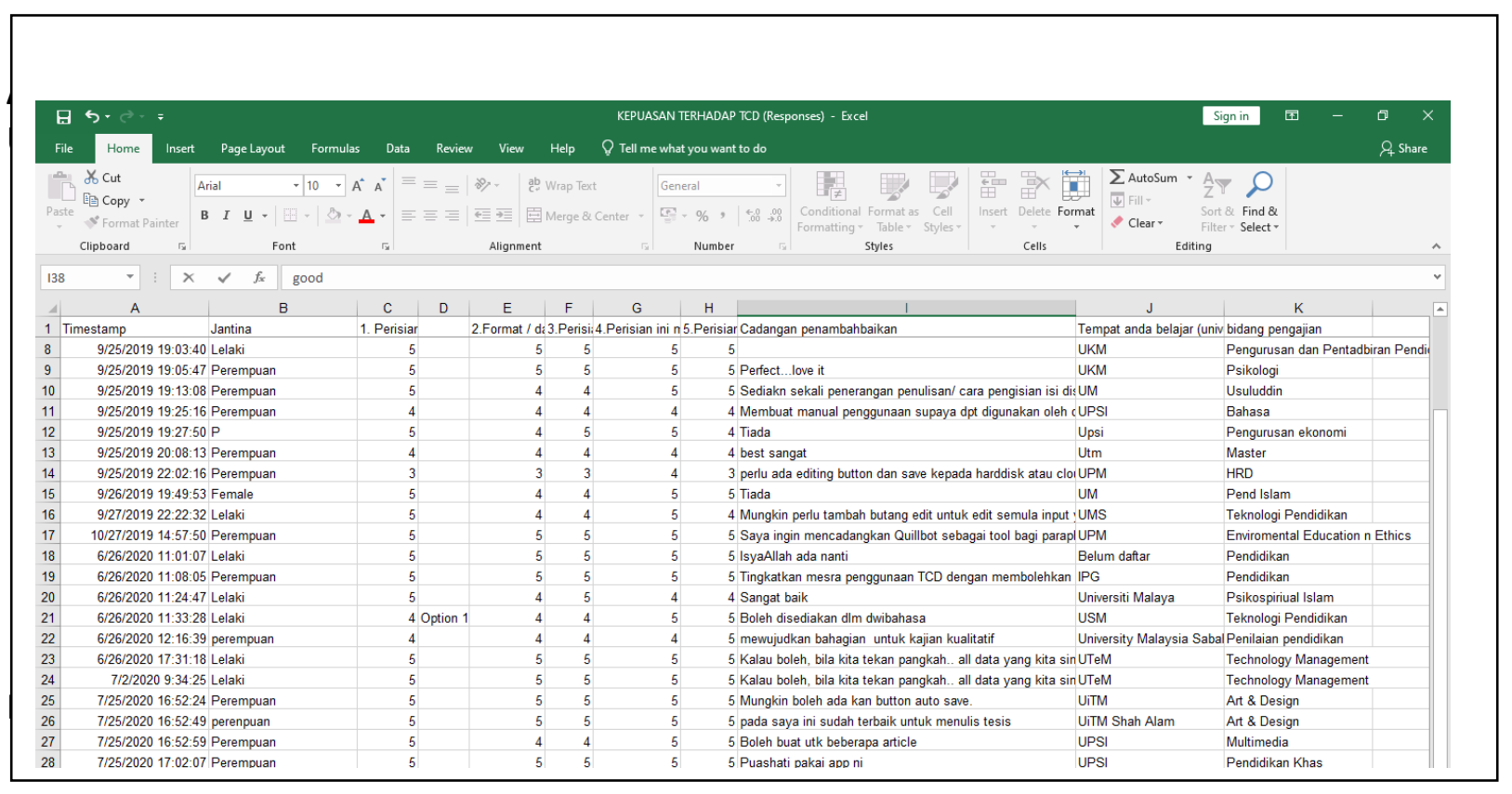




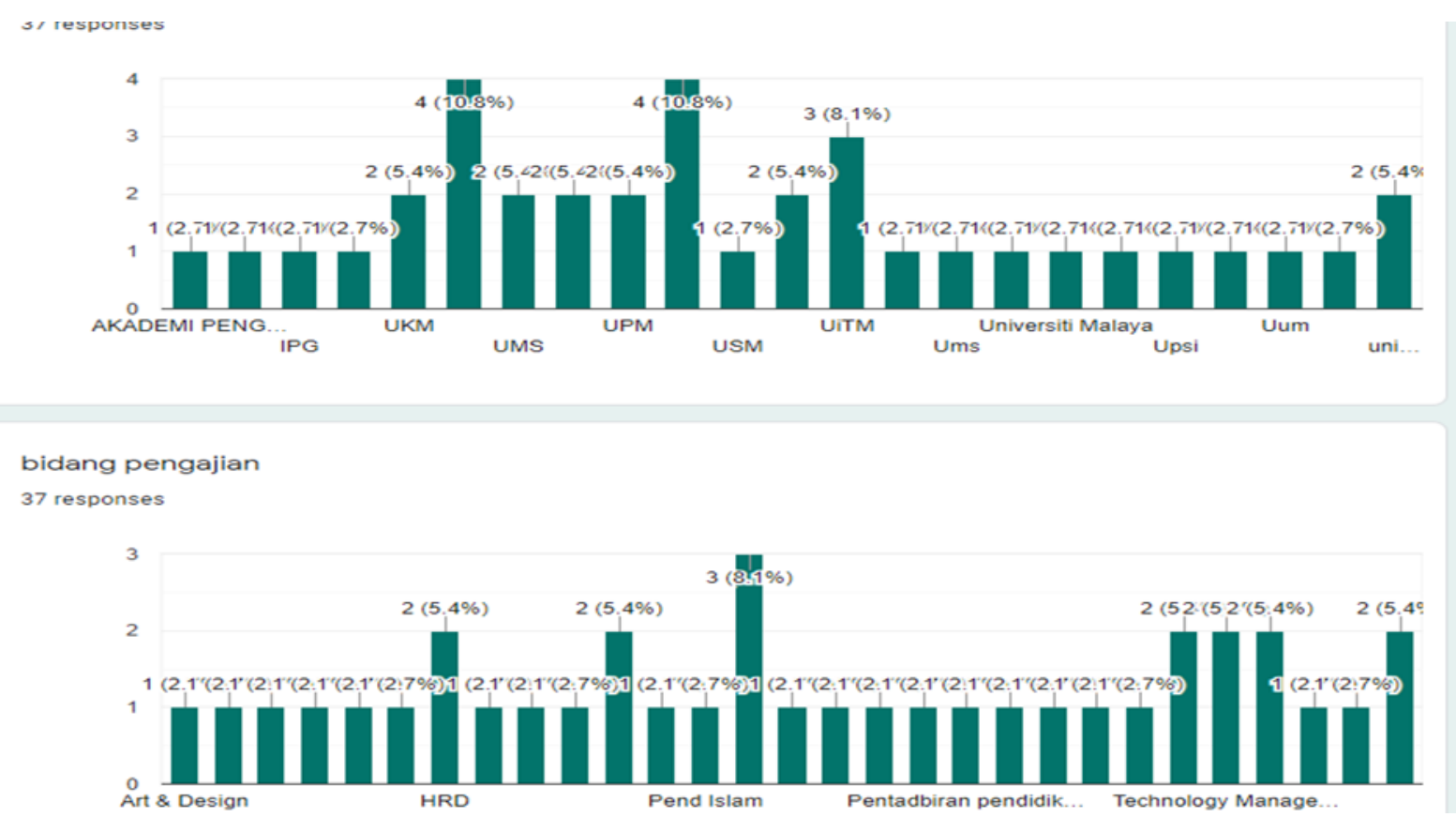

Figure 5: Respondent profiling \& Feedback

Based on figure 2, most of the 37 respondents who gave reactions were post graduate students from public universities in Malaysia. Students who answered the effectiveness questionnaire consisted of various fields namely Art \& Design, Human resources, Islamic Study, Education study \& technology management. There are also some users from Indonesia (5 users).

Table 1: Satisfaction data

\begin{tabular}{ll}
\hline Responces & Percentage \\
\hline The software is easy to use & $75.5 \%$ \\
The format / data is very easy to understand & $94.8 \%$ \\
User friendly & $85 \%$ \\
This software meets my writing needs & $78.4 \%$ \\
\hline The above data was obtained from a customer satisfaction questionnaire administered using \\
google form
\end{tabular}

\section{Impact to the User}

Quantitative findings

This software directly assists researchers, especially students, in preparing to write their research proposals. This innovation focuses on the understanding and skills in organizing important information necessary in academic writing. As an added value, this TCD software can improve users' skills and understanding of problem-solving in academic writing. Based on the survey data (refer table 1), most users of this software are satisfied with this software (75\%) admitted "the software is easy to use", "the software is user friendly" (85\%), (95\%) "easy to understand" and "this software meets the writing needs" (78.4\%). This data shows that users can make improvements to their academic writing by using technology (TCD software). 
Qualitative Findings

The results of semi -structured interviews conducted on 7 users, the findings showed that most users expressed satisfaction and stated that the software is very helpful in organizing and facilitating in their academic writing, especially thesis writing. The results of the interviews are as follows:

\begin{tabular}{ll}
\hline Participants & statements \\
\hline Participant 1 & "I think this software is very helpful to me, before this I wrote \\
& unfocused and unstructured. by using this software, I can organize \\
& my data well " \\
"At first I wrote the thesis only with reference to previous writings \\
only. by using this App, I can write well" \\
"This software helps me a lot. It seems easier for me to write and \\
Participant 3 & $\begin{array}{l}\text { "I think, this software really helps me. It's easy for me to use in } \\
\text { writing" } \\
\text { Participant 4 }\end{array}$ \\
"I'm a new student, and I don't know much. So, this software helps \\
Participant 5 a lot in my writing" \\
"My friend who introduced this software to me. I like this software \\
because he can help me in writing, especially in composing the \\
content of writing" \\
"My opinion, very helpful to me. I have been using this software for \\
almost 6 months. While using it, I noticed that my writing was \\
getting better and it seemed like it was easy for me to understand. \\
"
\end{tabular}

\section{Conclusion}

This software is a structured, innovative and systematic technological innovation project facilitating the process of academic writing, scientific journals and others. Systematic writing needs to be planned with a robust method to strengthen the writing in a structured manner. Therefore, this software is able to strengthen academic writing to be more structured, clear and systematic while educating the writer on the demands of writing for different purposes. Based on the findings also show that the use of technology is seen to be increasingly important in aiding academic writing. Quantitative and qualitative findings of this study found that users showed a positive reaction, and acknowledged that the use of technology is able to help in improving skills, quality on academic writing. Future researchers may be able to build better software especially in citation making and literature search to assist students in writing academic writing.

\section{References}

Abdul Kareem, M. N. (2013). An investigation study of academic writing problems faced by arab postgraduate students at Universiti Teknologi Malaysia (UTM). Theory and Practice in Language Studies. https://doi.org/10.4304/tpls.3.9.1552-1557

Amani, M. A. (2016). The Impact of Modern Technological Tools on Students Writing Skills in English as a Second Language. US-China Education Review A, 6(7), 438-443. https://doi.org/10.17265/2161-623x/2016.07.006 
Bannan-Ritland, B. (2003). The role of design in research: The integrative learning design framework. Educational researcher, 32(1), 21-24.

Cumming, A., Lai, C., \& Cho, H. (2016). Students' writing from sources for academic purposes: A synthesis of recent research. Journal of English for Academic Purposes. https://doi.org/10.1016/j.jeap.2016.06.002

Dymoke, Sue, \& Hughes, Janette. (2009). Using a poetry wiki: How can the medium support pre-service teachers of English in their professional learning about writing poetry and teaching poetry writing in a digital age? English Teaching: Practice and Critique, 8(3), 91-106

Ghahri, F., Hashamdar, M., \& Mohamadi, Z. (2015). Technology: A Better Teacher in Writing Skill. Theory and Practice in Language Studies. https://doi.org/10.17507/tpls.0507.24

Herrington, J., Oliver, R., \& Herrington, A. (2007). Authentic learning on the web: Guidelines for course design. In Flexible learning in an information society (pp. 26-35). IGI

Nobles, S., \& Paganucci, L. (2015). Do digital writing tools deliver? Student perceptions of writing quality using digital tools and online writing environments. Computers and Composition, 38, 16-31.

Takayoshi, Pamela, \& Selfe, Cynthia L. (2007). Thinking about multimodality. In Cynthia L. Selfe (Ed.), Multimodal Composition: Resources for Teachers (pp. 1-12). New Jersey: Hampton Press, Inc

Todorova, M., \& Koleva, E (2019). Academic writing and integration of technology. Electronics, vol.54, 7-8.

Reeves, D. B. (2006). The learning leader: How to focus school improvement for better results. ASCD.

Richey, R. C., \& Klein, J. D. (2007). Design and development research. Mahwah, NJ.

Richey, R. C., Klein, J. D., \& Nelson, W. A. (2004). Developmental Research: Studies of Instructional Design and Development. In D. H. Jonassen (Ed.), Handbook of research on educational communications and technology (pp. 1099-1130). Lawrence Erlbaum Associates Publishers.

Supriyadi, T., Saptani, E., Rukmana, A., Suherman, A., Alif, M. N., \& Rahminawati, N. (2020). Students' technological literacy to improve academic writing and publication quality. Universal Journal of Educational Research. https://doi.org/10.13189/ujer.2020.082238

Azizah, U. A., \& Budiman, A. (2018). CHALLENGES IN WRITING ACADEMIC PAPERS FOR INTERNATIONAL PUBLICATION AMONG INDONESIAN GRADUATES STUDENTS. JEELS (Journal of English Education and Linguistics Studies). https://doi.org/10.30762/jeels.v4i2.405

Van den Akker, J. (2007). Curriculum design research. An introduction to educational design research, 37.

Wilson, J., \& Czik, A. (2016). Automated essay evaluation software in English Language Arts classrooms: Effects on teacher feedback, student motivation, and writing quality. Computers and Education, 100, 94-109. https://doi.org/10.1016/j.compedu.2016.05.004 